\title{
PEMEROLEHAN KLAUSA RELATIF PADA PEMELAJAR BAHASA INDONESIA BAGI PENUTUR ASING (BIPA): KAJIAN BAHASA-ANTARA
}

\author{
Suharsono \\ FIB Universitas Gadjah Mada \\ email: hars_yogya@yahoo.com
}

\begin{abstract}
Abstrak
Penelitian ini bertujuan mendeskripsikan pemerolehan klausa relatif pemelajar BIPA tingkat madya, yang mencakup (a) bentuk klausa relatif, (b) urutan pemerolehan klausa relatif, dan (c) pengaruh penggunaan strategi belajar bahasa terhadap pemerolehan klausa relatif. Data diambil dari pemakaian bahasa Indonesia oleh pemelajar BIPA yang dihasilkan selama program kursus berlangsung dan isian kuesioner. Data kebahasaan dianalisis menggunakan metode padan-translasional dan metode agih, sedangkan data hasil kuesioner dianalisis dengan teknik penghitungan rerata dan persentase yang disajikan dalam bentuk tabulasi dan grafik. Kajian ini mendapatkan fakta bahwa penggunaan pronomina relatif yang merupakan butir yang tingkat pemerolehannya paling rendah, sedang tipe klausa relatif yang merelatifkan subjek menduduki tingkat tertinggi. Sementara itu, penggunaan strategi belajar bahasa berkorelasi positif terhadap pemerolehan klausa relatif. Penelitian ini memperoleh simpulan bahwa: (1) urutan pemerolehan klausa relatif menggambarkan sekaligus urutan penguasaan dan tingkat kesulitan setiap tipe, dan (2) penggunaan strategi belajar bahasa yang dilakukan secara sadar memungkinkan pencapaian pemerolehan klausa relatif lebih cepat.
\end{abstract}

Kata kunci: klausa relatif, pemerolehan klausa relatif, bahasa-antara, strategi belajar bahasa

\section{THE ACQUISITION OF RELATIVE CLAUSES BY BIPA LEARNERS: AN INTERLANGUAGE STUDY}

\begin{abstract}
This study aims to describe the acquisition of relative clauses by BIPA (Bahasa Indonesia for Foreigners) learners of the intermediate level, in terms of: (a) relative clause forms, (b) the sequence of relative clause acquisition, and (c) effects of language learning strategies on the relative clause acquisition. The data were collected from the use of Indonesian by BIPA learners attending a language program and through a questionnaire. The language data were analyzed by the translational equivalence and distributional methods and the questionnaire data by the calculation of means and percentages presented in tables and graphs. The results of the study showed that the use of the relative pronoun yang was the item with the lowest acquisition level and the relative clause type relativizing the subject was in the highest rank. Meanwhile, the use of language learning strategies had a positive correlation with the relative clause acquisition. The study concludes that: (1) the sequence of the relative clause acquisition reflects both the sequence of mastery and the difficulty level of of each clause type, and (2) the use of language learning strategies enables learners to acquire relative clauses faster.
\end{abstract}

Keywords: relative clause, relative clause acquisition, BIPA, interlanguage, language learning strategies 


\section{PENDAHULUAN}

Kajian mengenai pemerolehan bahasa Indonesia sebagai bahasa asing belum banyak dilakukan, padahal penggunaan bahasa Indonesia sebagai bahasa asing (BIPA), baik dalam bidang pengajaran maupun bidang lainnya, telah mengalami peningkatan. Kini bahasa Indonesia dipelajari dan diajarkan di berbagai belahan dunia. Tidak kurang dari 73 negara, yang terdiri dari 178 lembaga yang mengajarkan bahasa Indonesia sebagai bahasa asing. Di dalam negeri pun pengajaran BIPA diselenggarakan di berbagai perguruan tinggi maupun lembaga-lembaga lainnya yang bukan perguruan tinggi, dan terdapat tidak kurang dari 44 lembaga yang menyelenggarakan program BIPA (Biro Perencanaan dan Kerjasama Luar Negeri Kemendiknas, 2007). Selanjutnya, pada tahun 2014 jumlah lembaga ini bertambah menjadi sekitar 60 lembaga yang pada umumnya menyelenggarakan program Darmasiswa Republik Indonesia (darmasiswa.kemendikbud.go.id).

Selaras dengan diterbitkannya UU Nomor 24 Tahun 2009 tentang Bendera, Bahasa, dan Lambang Negara, serta Lagu Kebangsaan yang menegaskan fungsi bahasa Indonesia sebagai bahasa resmi dalam komunikasi nasional bagi seluruh lapisan masyarakat, tuntutan penggunaan bahasa Indonesia oleh penutur asing di dalam negeri akan semakin meningkat pada masa-masa mendatang. Tuntutan ini akan mendorong kemungkinan peningkatan permintaan pengajaran BIPA, baik di dalam maupun luar negeri. Dalam kondisi seperti ini upaya untuk senantiasa meningkatkan kualitas pengajaran BIPA merupakan suatu keniscayaan. Dengan demikian, jelas bahwa penelitian yang mendalam, berkelanjutan, dan lintas disiplin yang berhubungan dengan BIPA sangat diperlukan demi kemajuan BIPA pada masa depan.

Dalam empat KIPBIPA (Konferensi Internasional Pengajar BIPA) pertama, yaitu antara 1994-2001, kebanyakan kajian yang dibahas berbasis pengalaman dan sedikit yang berdasarkan penelitian. Topik-topik materi ajar, pengembangan kurikulum atau program, metodologi atau teknik mengajar, multimedia, dan kebudayaan merupakan topik-topik yang mendominasi dalam konferensi tersebut. Bidang-bidang kajian bahasa-antara (interlanguage), tes bahasa, ragam bahasa, dan persepsi pemelajar kurang diminati (Alwasilah, 2006). Begitu juga pada empat KIPBIPA berikutnya (sampai dengan KIPBIPA VIII tahun 2012) kajian yang berkenaan dengan empat topik di atas masih belum menarik minat peneliti dan penggiat BIPA.

Dua penelitian yang berkenaan dengan bahasa Indonesia sebagai bahasa asing adalah penelitian Kartika (2006) dan Muliastuti (2006), yang keduanya berfokus pada analisis kesalahan. Penelitian Kartika (2006), yang menggunakan subjek penelitian pemelajar BIPA dari Jepang, menyimpulkan bahwa sebenarnya pemelajar BIPA Jepang mengetahui berbagai strategi tindak tutur memohon. Pengetahuan tersebut mereka peroleh dari pengalaman mereka menyimak ujaran dosen selama berinteraksi di kelas dan teman Indonesia di luar kelas. Akan tetapi, tidak semua tindak tutur memohon yang dituturkan pemelajar BIPA Jepang berterima dan santun. Untuk menguasainya, pemelajar memerlukan contoh nyata bagaimana menggunakan tindak tutur tidak-langsung secara tepat. Selanjutnya, analisis kesalahan terhadap contoh-contoh kata, frasa, dan kalimat bahasa Indonesia dalam Kamus Bahasa Indonesia-Korea adalah penelitian yang dilakukan Muliastuti (2006). Meskipun penelitian ini tidak menggunakan subjek penelitian pemelajar BIPA, tetapi karena kamus tersebut disusun oleh orang Korea dan bahwa kamus itu memiliki peran penting bagi pemelajar BIPA dari Korea, maka penelitian ini dapat dimasukkan 
sebagai salah satu jenis analisis kesalahan. Berdasarkan kajiannya, Muliastuti (2006) menyimpulkan bahwa terdapat kesalahan yang cukup signifikan pada contoh-contoh bahasa Indonesia di dalam Kamus Bahasa Indonesia-Korea Modern (Edisi Kedua) susunan Ahn Young Ho tersebut. Kesalahan-kesalahan itu disebabkan oleh faktor interferensi dan faktor intrabahasa. Faktor intrabahasa meliputi kesalahan yang terjadi karena penyamarataan yang berlebih, ketidaktahuan batas kaidah, penerapan kaidah yang tidak sempurna, dan salah menghipotesiskan konsep.

Sementara itu, penelitian yang mendalami masalah urutan pemerolehan aspek-aspek tata bahasa bahasa Indonesia sebagai bahasa asing masih langka. Penelitian yang ada umumnya mengambil objek kajian bahasa Inggris sebagai bahasa asing atau kedua. Untuk konteks Indonesia, penelitian Nurmayanti (2012) dapat disebut sebagai salah satu contoh penelitian yang berada dalam ranah tersebut. Penelitiannya mengkaji pemerolehan bahasa Inggris sebagai bahasa kedua pada siswa Briton International School, yang meliputi pemerolehan kata, pemerolehan kalimat, dan faktor-faktor yang mendukung pemerolehan bahasa Inggris.

Berdasarkan pertimbangan di atas, penelitian ini mengambil salah satu topik kajian, yaitu bahasa-antara (interlanguage). Pada tahap bahasa-antara ini akan terlihat bagaimana proses pemerolehan atau penguasaan bahasa asing terjadi (Ellis, 2003: 34). Bahasa-antara adalah situasi (penguasaan) kebahasaan yang menggambarkan bahwa pemelajar bahasa asing mengonstruk sebuah sistem linguistis yang sebagian diambil dari bahasa pertamanya (B1) tetapi berbeda dengan B1 tersebut dan berbeda pula dengan bahasa target (bahasa asing/B2). (Ellis, 2003: 33; VanPatten \& Benati, 2010: 100).

Salah satu aspek tata bahasa yang diteliti dalam bahasa-antara ini adalah pemerolehan klausa relatif. Ada tiga ala- san dipilihnya topik ini. Pertama, penelitian terhadap pemerolehan klausa relatif dalam bahasa Indonesia belum pernah dilakukan. Kedua, klausa relatif merupakan salah satu masalah yang dihadapi pemelajar BIPA dalam memproduksinya. Dengan mengkaji klausa relatif, dapat diungkapkan jenis dan tingkat kesulitan yang dihadapi pemelajar BIPA dalam memproduksi klausa relatif. Ketiga, pemerolehan atau penguasaan klausa relatif melibatkan penguasaan aspek tata bahasa lainnya secara terpadu, seperti afiks, verba bentuk aktif dan pasif, pilihan kata, dan struktur frasa. Penelitian ini diharapkan dapat mengisi kelangkaan kajian di bidang pemerolehan tata bahasa BIPA dan diharapkan memberikan kontribusi di bidang pengajaran BIPA, khusunya pengembangan materi ajar BIPA.

Selanjutnya, karena perbedaan individu merupakan faktor penting yang membantu dalam mengidentifikasi penyebab munculnya gejala lingual dalam pemerolehan bahasa asing (Ellis, 2003: 7378), dalam mendeskripsikan pemerolehan klausa relatif perlu diperhitungkan kemungkinan perbedaan individual tersebut. Perbedaan itu kemungkinan akan menyebabkan perbedaan dalam: (1) bentuk lingual yang dihasilkan, (2) tingkat kecepatan pemerolehan, dan (3) urutan pemerolehan. Perbedaan individual dapat menyangkut banyak faktor, misalnya motivasi (Ellis, 2003; Gass \& Selinker, 2001), usia, sikap, strategi belajar (bahasa) (Saville-Troike, 2006: 82-92), dan jumlah waktu belajar (Abdul-Hamied, 2001: 2), tetapi dalam penelitian ini hanya akan dipertimbangkan faktor strategi belajar bahasa. Dalam hal ini akan dilihat pengaruh penggunaan strategi belajar bahasa terhadap pemerolehan klausa relatif.

Tujuan penelitian ini adalah mendeskripsikan bentuk klausa relatif yang dihasilkan oleh pemelajar BIPA, menjelaskan urutan pemerolehan klausa relatif bahasa Indonesia, dan mengungkapkan 
pengaruh penggunaan strategi belajar bahasa terhadap pemerolehan klausa relatif. Penelitian ini memiliki hipotesis bahwa pemerolehan klausa relatif akan mendorong terjadinya pergeseran identitas tuturan dan "identitas" tersebut dapat diungkap melalui produksi bahasa atau kalimatnya.

Bahasa-antara adalah bahasa yang mengacu kepada sistem bahasa di luar sistem bahasa pertama atau bahasa yang dituturkan pemelajar (selanjutnya disingkat B1) dan kedudukannya berada di antara B1 dan B2 (bahasa kedua/asing). Oleh karena itu, bahasa-antara merupakan suatu sistem linguistis yang unik (Ellis, 2003: 33). Konsep bahasa-antara menawarkan suatu catatan umum bagaimana pemerolehan B2 terjadi. Dalam kaitan ini premis-premis tentang bahasaantara yang dikemukakan Ellis (2003: 3334) layak dijadikan pijakan teoretis. Di sini akan dikemukakan empat premis yang berhubungan erat dengan penelitian ini. Pertama, pemelajar mengonstruk sebuah sistem kaidah linguistik yang abstrak yang mendasari pemahaman dan produksi B2. Sistem kaidah ini merupakan 'tata bahasa mental' dan merujuk pada sebuah 'bahasa-antara'. Kedua, tata bahasa pemelajar terbuka terhadap pengaruh dari luar (yaitu melalui input) dan dari dalam. Ketiga, tata bahasa pemelajar bersifat transisional. Pemelajar mengubah tata bahasanya dari waktu ke waktu dengan menambahkan kaidah, menghilangkan kaidah, dan menyusun kembali seluruh sistem. Hal ini menghasilkan sebuah 'kontinuum bahasa-antara', yakni pemelajar mengonstruk suatu rangkaian tata bahasa mental atau bahasa-antara sampai secara bertahap meningkat kompleksitas pengetahuan B2-nya. Keempat, pemelajar menerapkan berbagai strategi belajar untuk mengembangkan bahasa-antaranya. Jenis-jenis kesalahan yang berbeda yang diproduksi pemelajar mencerminkan strategi belajar yang berbeda.
Dalam proses pemerolehan, menurut hipotesis urutan alamiah, unsur-unsur bahasa dan kaidah bahasa diperoleh dalam urutan yang dapat diprediksi (Krashen (1982: 34), artinya bahwa tidak setiap pemerolehan sekaligus akan memperoleh struktur bahasa dalam urutan yang persis sama. Dengan kata lain, struktur atau butir gramatikal tertentu berkemungkinan akan diperoleh lebih cepat bila dibandingkan dengan yang lainnya.

Selanjutnya, karena bidang kajian pemerolehan bahasa asing memusatkan perhatian pada pendeskripsian dan pemahaman dinamika proses belajar bahasa, pengukuran dalam pemerolehan bahasa layak dijadikan pertimbangan dalam penelitian ini. Hal ini karena pengukuran memberikan bukti bagi interpretasi terhadap perkembangan atau perubahan dalam sistem linguistik pemelajar (Norris \& Ortega, 2003: 717). Dengan kata lain, pengukuran menjadi wahana penting untuk menjelaskan tingkat perkembangan atau perubahan dalam pemerolehan bahasa asing. Dalam penelitian ini pengukuran atau penghitungan secara kuantitatif diterapkan pada pembahasan yang terkait dengan urutan pemerolehan dan penggunaan strategi belajar bahasa.

\section{METODE}

Penelitian ini mengambil subjek pemelajar dewasa (adult learner). Pemelajar dewasa merupakan pemelajar BIPA yang memiliki karakteristik psikologis, sosial, kemampuan penguasaan bahasa, dan gaya belajar yang berbeda dengan pemelajar anak-anak. Meski pemelajar dewasa sering dianggap sebagai "pemelajar yang miskin bahasa" karena plastisitas otak yang dicapai pada "periode kritis" telah berkurang dan menyebabkan pemerolehan bahasa asing menjadi lebih sulit dibandingkan pada masa sebelumnya, tetapi pemelajar dewasa telah siap mengembangkan strategi belajar dan mampu menggunakannya untuk mem- 
bantunya dalam mempelajari bahasa (Lenneberg, 1967 via Schleppegrell, 1987: 2).

Pemelajar yang dijadikan subjek penelitian ini adalah lima pemelajar BIPA tingkat madya yang belajar bahasa dan budaya Indonesia di Inculs, Fakultas Ilmu Budaya UGM, pada semester kedua 2012/2013. Semuanya berasal dari Amerika Serikat. Perlu dikemukakan di sini bahwa pada saat penelitian ini dilakukan standar kemahiran yang digunakan Inculs tidak sepenuhnya mengacu pada Common European Framework of Reference for Language (CEFR). Akan tetapi, bila dilihat silabus dan buku ajar yang digunakan, dapat disimpulkan bahwa tingkat madya Inculs ini setara dengan tingkat B2 model CEFR. Sebelum ada standar pemeringkatan kemahiran BIPA yang baku di Indonesia, standar kemahiran model CEFR dapat dijadikan rujukan. CEFR merupakan standar kemahiran berbahasa yang awalnya menjadi rujukan bagi bahasa-bahasa di kawasan Eropa, tetapi kini diadposi pula di kawasan lain di luar Eropa, termasuk beberapa bahasa di Asia, seperti Jepang, Mandarin, Korea (Kakazu, 2011; Wiedarti, 2010). CEFR membagi skala kemahiran berbahasa atas enam tingkat, yaitu A1, A2, B1, B2, C1, dan C2. Tingkat A1 merupakan peringkat kemahiran yang terendah dan C2 merupakan peringkat kemahiran tertinggi. Masing-masing tingkat memiliki deskriptor yang menunjukkan tingkat kemahiran berbahasa yang harus dikuasai oleh pemelajar (Language Policy Division, Council of Europe, 2001). Di Indonesia pada umumnya lembaga penyelenggara pengajaran BIPA membagi peringkat kemahiran atas tiga tingkat, yaitu dasar, madya/menengah, dan lanjut. Bila dihubungkan dengan CEFR, tingkat dasar secara garis besar merujuk tingkat A1 dan A2, tingkat madya merujuk B1 dan B2, dan tingkat lanjut merujuk C1 dan C2. Dalam artikel ini masalah standar pemeringkatan BIPA tidak dibicarakan secara rinci karena artikel ini hanya berfokus pada masalah pemerolehan (klausa relatif) dan bukan perkembangan pemerolehan dari satu tingkat ke tingkat berikutnya. Untuk menjaga kerahasiaan individu, dalam artikel ini nama pemelajar sengaja tidak ditampilkan secara eksplisit kecuali hanya dalam bentuk singkatan.

Data yang digunakan sebagai bahan analisis adalah tuturan dan tulisan pemelajar BIPA yang dihasilkan selama program kursus berlangsung dan isian kuesioner. Metode pengumpulan data yang berhubungan dengan pemakaian bahasa dilakukan dengan teknik naturalistik (Chaudron, 2003). Dalam teknik naturalistik, data dijaring berdasarkan hasil tuturan atau tulisan yang alami, yang dipakai dalam konteks riil, seperti wawancara spontan, observasi kelas, pemberian tugas menulis mengenai topik tertentu, dsb. Dari keseluruhan klausa yang diproduksi pemelajar dan terjaring dalam penelitian, terdapat 124 klausa relatif yang dijadikan sebagai bahan analisis. Adapun pengumpulan data yang menggunakan kuesioner diterapkan untuk menjaring data yang berhubungan dengan upaya untuk mengungkap strategi belajar bahasa pemelajar. Dengan kuesioner tersebut, peneliti mendapat data kualitatif dari responden mengenai hal-hal yang terkait dengan strategi belajar yang digunakan dalam meningkatkan atau mengembangkan pemerolehan klausa relatif. Dalam analisis data lingual digunakan metode padan-translasional dan metode agih (Sudaryanto, 1993), sedangkan untuk data hasil kuesioner digunakan teknik penghitungan rerata dan persentase yang disajikan dalam bentuk tabulasi dan grafik.

\section{HASIL DAN PEMBAHASAN}

Klausa relatif adalah klausa terikat yang diawali oleh pronomina relatif yang (Kridalaksana, 2008: 125) dan fungsinya mendeskripsikan sebuah nomina atau frasa nomina yang terdapat di dalam 
klausa utama (DeCapua, 2008: 319). Dalam klausa relatif, pronomina relatif yang merupakan penentu bagi unsur yang direlatifkan. Berdasarkan unsur yang direlatifkan, terdapat lima tipe klausa relatif, yaitu: (1) klausa relatif yang merelatifkan subjek, (2) klausa relatif yang merelatifkan objek, (3) klausa relatif yang merelatifkan unsur termilik, (4) klausa relatif yang menghilangkan unsur nomina; dan (5) klausa relatif yang merelatifkan predikat. Berikut ini berturut-turut dikemukakan masing-masing dua contoh untuk setiap tipe.

(1) a. Wanita yang berkebaya dapat melewati pintu sebelah kanan.

b. Peserta yang akan mengikuti tes kesehatan diharap masuk melalui pintu samping.

(2) a. Wanita yang dicari Jennifer itu ternyata sudah berpindah tempat tinggal.

b. Wanita yang saya cari itu ternyata sudah berpindah tempat tinggal.

Kalimat (2.a) berasal dari (2.a.1) dan (2.b.1). Setelah objeknya (wanita itu) direlatifkan, maka terbentuklah kalimat (2.a).

(2) a.1. Jennifer mencari wanita itu.

(2) a.2. Wanita itu ternyata sudah berpindah tempat tinggal.

(3) a. Wanita yang suaminya bekerja di toko swalayan itu ternyata sudah berpindah tempat tinggal.

b. Kampung yang warganya suka bergotong royong itu mendapat penghargaan.

(4) a. Di sana ada beberapa mahasiswa yang berdiskusi. Yang duduk berasal dari Jerman dan yang berdiri dari Jepang.

b. Di ruang minum beberapa mahasiswa sedang berdiskusi. Ada yang berdiskusi tentang budaya, politik, dan ada juga yang berdiskusi tentang kuliner.
Baik pada contoh (4.a) maupun (4.b), unsur nomina mahasiswa, yang sudah disebut pada kalimat sebelumnya, mengalami pelesapan pada kalimat kedua. Apabila nomina tersebut dihadirkan, kalimatnya menjadi (4.a.1) dan (4.b.1) berikut ini.

(4) a.1. Di sana ada beberapa mahasiswa yang berdiskusi. Mahasiswa yang duduk berasal dari Jerman dan mahasiswa yang berdiri dari Jepang.

(4) b.1. Di ruang minum beberapa mahasiswa sedang berdiskusi. Ada mahasiswa yang berdiskusi tentang budaya, politik, dan ada juga mahasiswa yang berdiskusi tentang kuliner.

(5) a. Dia yang memasaknya, bukan saya. b. Wanita itulah yang dicari Jennifer.

Dari contoh-contoh tersebut tampat bahwa pembentukan klausa relatif mengikutkan dua ciri lingual, yaitu kehadiran pronomina relatif yang dan demonstrativa inilitu. Kehadiran pronomina relatif yang bersifat wajib, sedangkan kemunculan demonstrativa ini/itu bersifat opsional. Dengan demikian, dapat dikatakan bahwa pronomina relatif yang merupakan penanda klausa relatif. Meskipun kehadiran demonstrativa ini/itu bersifat opsional, fungsi yang dimainkan sebagai pembatas bagi frasa nominal yang direlatifkan menjadikan demonstrativa tersebut memiliki peran penting dalam kaitannya dengan penguasaan klausa relatif bagi pemelajar BIPA.

\section{Tipe Kesalahan Penggunaan Klausa Relatif oleh Pemelajar BIPA}

Salah satu hal penting yang perlu dideskripsikan berkaitan dengan pemerolehan bahasa asing adalah bentuk lingual yang diproduksi oleh pemelajar. Deskripsi tersebut terutama berkaitan dengan bentuk-bentuk kesalahan karena dalam situasi bahasa-antara pemelajar berkemungkinan melakukan kesalahan 
karena ketidaktahuan atau belum dikuasainya kaidah. Inilah yang disebut dengan analisis kesalahan. Analisis kesalahan, dengan demikian, merupakan bagian yang tidak boleh dilewatkan manakala melakukan pendeskripsian terhadap pemerolehan bahasa asing sebab di sinilah tercermin suatu proses pemerolehan dalam masa transisi (Ellis, 2003: 23). Hal itu juga selaras dengan premis yang dikemukakan Ellis (2003: 33-34), khususnya premis ketiga, yang menyatakan bahwa tata bahasa pemelajar bersifat transisional. Pemelajar mengubah tata bahasanya dari waktu ke waktu dengan menambahkan kaidah, menghilangkan kaidah, dan menyusun kembali seluruh sistem. Berdasarkan analisis terhadap kesalahan tersebut, dapat dilihat dan ditentukan urutan pemerolehan, kecepatan pemerolehan, dan tahapan perkembangan bahasa-antara.

Sebelum dipaparkan tipe-tipe kesalahan, perlu dikemukakan di sini bahwa tidak semua tipe klausa relatif ditemukan dalam kalimat-kalimat yang diproduksi oleh pemelajar BIPA. Dari lima tipe klausa relatif yang telah dikemukakan pada bagian sebelumnya, hanya tiga tipe yang terwakili dalam data atau muncul dalam data, yaitu tipe 1 (klausa relatif yang merelatifkan subjek), tipe 2 (klausa relatif yang merelatifkan objek), dan tipe 4 (klausa relatif yang menghilangkan unsur nomina). Tipe 3 (klausa relatif yang merelatifkan unsur termilik) dan tipe 5 (klausa relatif yang merelatifkan predikat) tidak muncul karena kedua tipe itu lebih sulit penguasaannya daripada ketiga tipe lainnya. Selain itu, klausa relatif tipe 3 dan 5 merupakan topik tata bahasa yang tingkat penguasaannya menjadi target kompetensi pada tingkat lanjut, sementara pemelajar yang dijadikan subjek penelitian ini adalah pemelajar yang berada di tingkat madya. Tipe 4 hanya ditemukan kemunculannya pada satu pemelajar. $\mathrm{Hal}$ itu menunjukkan bahwa kemampuan berbahasa seorang pemelajar ini memang lebih cepat dibandingkan dengan lainnya. Hal ini berarti pula bahwa pemerolehan klausa relatifnya lebih cepat dibandingkan dengan pemelajar lainnya. Selanjutnya, diuraikan bentuk-bentuk kesalahan yang ditemukan dalam tuturan subjek penelitian.

Pertama, kesalahan karena tidak digunakannya pronomina relatif yang. Pada tipe kesalahan ini pemelajar tidak menggunakan pronomina relatif yang yang seharusnya digunakan. Contohnya adalah kalimat (6) dan (7) berikut ini, dengan kalimat (6a) dan (7a) sebagai pembetulannya.

(6) Di Yogyakarta, orang harus lebih hati-hati karena di Amerika biasanya orang bisa berjalan lurus. Juga ada lampu merah berbeda di sini.

(6a) Di Yogyakarta, orang harus lebih hati-hati karena di Amerika biasanya orang bisa berjalan lurus. Selain itu, ada lampu merah yang berbeda di sini.

(7) Mereka tinggal di rumah diberi kepada mereka oleh UGM.

(7a) Mereka tinggal di rumah yang diberikan kepada mereka oleh UGM.

Kesalahan pada (7) juga terletak pada kekuranglengkapan afiks pada verba diberi. Di sini sekaligus juga mencerminkan bahwa kaidah penggunaan afiks belum sepenuhnya dikuasai.

Kedua, kesalahan penempatan demonstrativa itu/ini. Sebagaimana dikemukakan pada bagian depan bahwa dimungkinkan dalam klausa relatif muncul demonstrativa ini/itu. Dalam klausa relatif, demonstrativa ini/itu memiliki fungsi sebagai pembatas bagi frasa nomina yang direlatifkan. Maksudnya, unsur yang berada di sebelah kiri ini/itu merupakan sebuah frasa tersendiri, sedangkan unsur di sebelah kanannya merupakan kata atau frasa lain. Meski demonstrativa ini/itu bersifat opsional, fungsi yang dimainkan sebagai pembatas bagi frasa nominal yang direla- 
tifkan menjadikan demonstrativa tersebut memiliki peran penting dalam kaitannya dengan penguasaan klausa relatif bagi pemelajar BIPA. Kesalahan yang ditemukan adalah demonstrativa ini/itu tidak ditempatkan pada bagian akhir klausa relatif, melainkan di belakang nomina/ frasa nomina yang direlatifkan. Kalimat (8) dan (9) sekadar contoh tipe kesalahan yang termasuk ke dalam tipe kedua ini. Adapun (8a) dan (9a) masing-masing merupakan kalimat pembetulan dari (8) dan (9).

(8) Tulisan itu yang diceritakan oleh artikel "Kisah Cinta dari Cina" sangat menarik.

(8a) Tulisan yang diceritakan oleh artikel "Kisah Cinta dari Cina" itu sangat menarik.

(9) Orang itu yang terlihat semangat berhasil memecahkan rekor dunia.

(9a) Orang yang terlihat semangat itu berhasil memecahkan rekor dunia.

Ketiga, kesalahan pada klausa relatif yang merelatifkan subjek. Jenis kesalahan tipe ini terletak pada penggunaan afiks pada verba aktif. Verba yang seharusnya berafiks, tetapi tidak diberi afiks. Pada contoh (10) verba bicara seharusnya berbicara, pada (11) verba nikah seharusnya menikah, dan pada (12) verba ikut seharusnya mengikuti/menyertai.

(10) Ada bermacam-macam pilihan, seperti kerja dengan anak miskin atau anak di Chinatown yang tidak bisa bicara bahasa Inggris bagus.

(10a) Ada bermacam-macam pilihan, seperti kerja dengan anak miskin atau anak di Chinatown yang tidak bisa berbicara bahasa Inggris dengan bagus.

(11) Ada banyak macam-macam pernikahan di Amerika. Masalah pernikahan tergantung kepada orang yang nikah.

(11a) Masalah pernikahan tergantung orang yang menikah.
(12) Ini karena ada banyak tanggung jawab yang ikut pernikahan, terutama jika suami istri punya anak.

(12a) Ini karena ada banyak tanggung jawab yang mengikuti (menyertai) pernikahan, terutama jika suami istri punya anak.

Keempat, kesalahan pada klausa relatif yang merelatifkan objek. Kesalahan jenis ini dibagi atas empat subtipe berdasarkan pada bentuk verba pasif yang berada di belakang pronomina relatif yang. Dalam bahasa Indonesia perelatifan objek menyebabkan verba dalam klausa relatif berubah menjadi pasif. Di sini verba pasif dibedakan atas dua tipe, yaitu verba pasif berprefiks di- dan verba pasif persona. Verba pasif persona adalah verba yang dalam pemasifannya tidak menggunakan prefiks $d i-$, melainkan berupa verba dasar yang didahului pronomina persona pertama atau kedua. Pembedaan atas dua bentuk pasif ini didasarkan pada tingkat kesulitan pemerolehan terhadap verba bentuk pasif tersebut. Pada umumnya pemerolehan bentuk pasif persona lebih lambat dibandingkan dengan bentuk pasif $d i$.

Sebagaimana disebutkan di atas, kesalahan pada klausa relatif yang merelatifkan objek dibagi atas empat subtipe. Pengelompokkan subtype tersebut berdasarkan pada bentuk verba pasif yang berada di belakang pronomina relatif yang. Keempat subtipe yang dimaksud, yaitu: (a) kesalahan penggunaan afiks pada verba pasif $d i-$, (b) kesalahan penempatan persona pada verba pasif persona, (c) kesalahan penggunaan bentuk verba pasif persona, dan (d) kesalahan penempatan adverbia pada bentuk pasif persona. Penjelasan terperinci diuraikan sebagai berikut.

Pertama, kesalahan penggunaan afiks pada verba pasif $d i$. Jenis kesalahan ini meliputi kesalahan karena (i) verbanya tidak berprefiks $d i$ - atau (ii) menggunakan 
prefiks di-secara tidak tepat. Klausa relatif pada data (13) dan (14) berkenaan dengan kesalahan jenis (i), sedangkan data (15) berkenaan dengan kesalahan jenis (ii). Adapun (13a), (14a), dan (15a) masingmasing merupakan pembetulannya.

(13) Orang terkenal dan model yang menggambarkan di dalam majalah ini adalah tidak contoh bagus untuk perempuan muda.

(13a) Orang terkenal dan model yang digambarkan di dalam majalah ini bukan contoh bagus bagi perempuan muda.

(14) Juga, pekerja kantor sering pakai seragam yang bermaksud untuk mengangkat rasa solidaritas dalam perusahaannya.

(14a) Juga, pekerja kantor juga sering memakai seragam yang dimaksudkan untuk mengangkat rasa solidaritas dalam perusahaannya.

(15a) Waktu saya belajar di S1 saya menemukan teori sosial dimenulis Marx dan Foucawlt.

(15a) Waktu saya belajar di S1, saya menemukan teori sosial yang ditulis Marx dan Foucawlt.

Pada data (13) verba menggambarkan seharusnya digambarkan, pada (14) verba bermaksud seharusnya dimaksudkan, dan pada (15) terdapat pencampuradukan antara $d i$ - dan $m e-$, yaitu verba dimenulis seharusnya ditulis.

Kedua, kesalahan penempatan persona pada verba pasif persona. Jenis kesalahan ini terjadi karena menempatkan persona di belakang verbanya padahal seharusnya unsur persona berada di depan verbanya. Kesalahan seperti ini terjadi karena pemelajar menerapkan kaidah pemasifan dengan $d i$ - untuk pemasifan pada tipe pasif persona ini, seperti pada data (16) berikut.

(16) Salah satu makanan khas Indonesia yang disukai saya (dan oleh banyak orang asing) adalah sate ayam. (16a) Salah satu makanan khas Indonesia yang saya sukai (dan oleh banyak orang asing) adalah sate ayam.

Pada data (17) berikut ini terdapat kesalahan bukan hanya karena menempatkan persona saya secara tidak tepat, tetapi juga terjadi pencampuradukan antara di- dan me-.

(17) Pakaian yang dimembeli saya di Amerika lebih mahal dari pada pakaian yang dimembeli saya di Indonesia atau India.

(17a) Pakaian yang saya beli di Amerika lebih mahal daripada pakaian yang saya beli saya di Indonesia atau India.

Mengingat bentuk dimembeli digunakan secara konsisten dalam dua buah klausa pada sebuah kalimat, hal ini memperlihatkan bahwa kesalahan penggunaan bentuk tersebut bukan karena kebetulan atau salah tulis, melainkan karena belum dikuasainya kaidah pemasifan.

Ketiga, kesalahan penggunaan bentuk verba pasif persona. Kesalahan pada bentuk pasif persona dapat pula berupa kesalahan pembentukan verbanya. Bentuk verba pada pasif persona yang seharusnya berupa verba dasar, dalam hal ini verba tanpa prefiks, digunakan verba berprefiks. Contohnya adalah data berikut ini.

(18) Sembarang informasi yang anda bisa menyediakan akan berguna saya.

(18a) Sembarang informasi yang bisa Anda sediakan akan berguna bagi saya.

Pada kalimat (18) verba menyediakan seharusnya berupa verba dasar tak berprefiks sediakan. Selain itu, penempatan pronomina persona Anda juga tidak benar karena seharusnya berada langsung di depan verbanya. Dalam hal ini kelihatan bahwa pemelajar masih belum menguasai kaidah pembentukan pasif persona sehingga belum mampu membedakan dengan baik antara bentuk verba aktif (karena personanya terletak di depan verba) 
dengan verba pasif persona (yang samasama pronomina personanya terletak di depan verba tak berprefiks). Tampak pula di sini bahwa tuturan B2-nya (bahasa Indonesia) dipengaruhi oleh struktur B1nya (bahasa Inggris) karena dalam bahasa Inggris verba atau frasa verba pada klausa relatif yang merelatifkan objek selalu berbentuk aktif. Struktur klausanya adalah nomina/frasa nomina + pronomina relatif + subjek/frasa nomina + frasa verba (aktif) (DeCapua, 2008: 324; Greenbaum, 1996: 586). Sebagai contoh, dapat diperhatikan dua kalimat berikut (kalimat (i) dikutip dari DeCapua (2008: 324) dan kalimat (ii) dikutip dari Greenbaum (1996: 586)).

(i) Astrid saw the movie that her friends had recommended.

(ii) Police say that they can't confirm a TV report that we all saw last night.

Pada kalimat (i) subjek/frasa nomina her friends berada di depan frasa verba had recommended yang berbentuk aktif dan pada kalimat (ii) subjek/frasa nomina we all berada di depan verba aktif saw.

Pada kasus kalimat (18), mengikuti struktur klausa relatif dalam bahasa Inggris, penutur berbahasa Inggris akan menuturkan kalimat tersebut menjadi (18b) berikut ini.

(18b) Any information that you could provide would be useful for me.

Contoh lain kesalahan jenis ini adalah kalimat (19) berikut ini.

(19) Baju yang saya akan mencuci adalah baju batik.

(19a) Baju yang akan saya cuci adalah baju batik.

Kesalahan jenis ini ditemukan bukan hanya verba transitif berafiks meN- seperti kedua contoh di atas, tetapi juga pada verba taktransitif, seperti pada contoh (20) berikut ini.

(20) Di Boston, kota yang saya sudah kuliah untuk empat tahun di universitas, ada banyak pengabdian.
Klausa relatif di atas seharusnya berbentuk (20a) berikut ini.

(20a) Di Boston, kota yang sudah saya tinggali untuk kuliah selama empat tahun di universitas, ada banyak pengabdian.

Keempat, kesalahan penempatan adverbia pada bentuk pasif persona. Dalam bahasa Indonesia adverbia, yaitu kategori kata yang dapat mendampingi adjektiva, verba, numeralia, atau proposisi dalam konstruksi sintaktis (Kridalaksana, 1986: 79), pada konstruksi pasif persona terletak di depan pronomina persona, seperti pada klausa buku itu sudah saya ambil. Kesalahan yang dilakukan oleh pemelajar BIPA adalah menempatkan adverbia di antara pronomina persona dan verba dasar seperti pada (21) berikut ini.

(21) Ada terlalu banyak benda-benda yang saya harus tulis tentang topik ini.

(21a) Ada terlalu banyak benda-benda yang harus saya tulis tentang topik ini.

Selanjutnya, terdapat catatan untuk klausa relatif yang menghilangkan unsur nomina. Sebagaimana telah dikemukakan pada bagian sebelumnya bahwa klausa relatif tipe 4, yaitu klausa relatif yang menghilangkan unsur nomina, ditemukan kemunculannya dalam data meski tipe 4 ini merupakan topik tata bahasa yang tingkat penguasaannya menjadi target kompetensi pada tingkat lanjut. Akan tetapi, kemunculannya hanya ditemukan pada seorang pemelajar. Yang menarik adalah bahwa dari 7 data yang diperoleh ternyata semuanya benar. Di sini kelihatan bahwa si pemelajar ini telah menguasai atau memperoleh kaidah klausa relatif tipe ini dengan baik. Berikut ini diberikan sebagian contoh klausa relatif tipe 4 yang dihasilkan oleh si pemelajar ini.

(22) Pada Minggu lalu, kami mengunjungi tiga tempat penting. Yang pertama yang akan kami kunjungi adalah Borobudur, yang kedua adalah Prambanan. Tetapi 
yang paling menarik adalah kraton Surakarta.

(23) Di warung itu ada beberapa mahasiswa yang berdiskusi. Yang sedang minum kopi adalah mahasiswa jurusan Sastra Perancis, dan yang minum teh belajar di Fakultas Hukum.

(24) Pak Suharjo punya empat anak. Yang bersuara indah bermimpi menjadi penyanyi terkenal.

\section{Pemerolehan Klausa Relatif}

Analisis kesalahan sebagaimana diuraikan pada pasal sebelumnya sekaligus memperlihatkan bagaimana pemelajar BIPA memproduksi klausa relatif. Hasil analisis kesalahan tersebut dapat dipakai sebagai dasar untuk menentukan urutan pemerolehannya. Urutan pemerolehan ini menggambarkan tipe klausa relatif mana yang mampu dikuasai oleh pemelajar lebih dulu dan mana yang lebih kemudian. Dengan demikian, urutan pemerolehan ini menggambarkan bagaimana kemampuan pemelajar secara kelompok dalam memproduksi klausa relatif. Inilah yang disebut dengan skor kelompok. Penentuan urutan pemerolehan dengan metode skor kelompok ini didasarkan pada asumsi bahwa semakin tinggi frekuensi kesalahan menandakan semakin lambat penguasaan terhadap butir kebahasaan tersebut. Sebaliknya, semakin rendah frekuensi terjadinya kesalahan menandakan bahwa semakin cepat penguasaan terhadap butir itu. Berdasarkan asumsi tersebut, dapat ditentukan 'hierarkhi' penguasaan klausa relatif. Butir yang dikuasai lebih lambat (yang frekuensi kesalahannya lebih tinggi) berarti bahwa butir tersebut berada pada hierarkhi bawah. Sebaliknya, butir yang dikuasai lebih cepat (yang frekuensi kesalahannya lebih rendah) berarti bahwa butir tersebut berada pada hierarkhi atas. Presentasi kesalahan disajikan pada Tabel 1.

Perlu dicatat bahwa tipe $5^{*}$ tidak diperhitungkan dalam urutan pemerolehan karena tipe tersebut hanya diproduksi oleh satu orang pemelajar dan hal itu dimungkinkan pemunculannya berkat kemampuan "istimewa" pemelajar tersebut yang berhasil mencapai tingkat lanjut atau tingkat $\mathrm{C} 1$ bila mengikuti standar pemeringkatan CEFR. Begitu juga tipe $2^{*}$ tidak diikutkan dalam urutan pemerolehan karena hanya diproduksi oleh seorang pemelajar.

Tabel 1 menunjukkan bahwa penggunaan pronomina relatif merupakan butir yang tingkat pemerolehannya paling rendah. Sementara itu, pemerolehan terhadap klausa relatif yang merelatifkan subjek menduduki tingkat tertinggi, yang mengandung arti bahwa butir inilah yang pemerolehannya paling cepat. Apabila keenam tipe tersebut diurutkan, akan tampak hierarkhinya sebagai berikut (dari yang cepat dikuasai menuju yang paling lambat): (1) klausa relatif yang merelatifkan subjek, (2) penempatan adverbia pada verba pasif persona, (3) penempatan persona pada verba pasif persona, (4) penggunaan afiks pada verba pasif $d i-$, (5) penggunaan prefiks pada verba pasif persona, dan (6) penggunaan pronomina relatif yang.

Tipe klausa relatif yang merelatifkan subjek menduduki tempat yang paling cepat pemerolehannya karena (i) proses pembentukannya sama dengan B1 pemelajar (bahasa Inggris), yakni tinggal menempelkan klausa relatif pada unsur subjek, dan (ii) dalam proses perelatifannya tidak menuntut perubahan bentuk pada verba maupun posisi nominanya (unsur subjek). Sebaliknya, pemerolehan terhadap penggunaan pronomina relatif yang menduduki hierarkhi yang terbawah karena dipengaruhi oleh faktor interferensi B1. Dalam bahasa Inggris (B1) kehadiran pronomina relatif, khususnya yang merelatifkan objek, tidak bersifat wajib (lihat DeCapua, 2008: 327; Leech et. al, 1982: 98), sedangkan dalam bahasa Indonesia bersifat wajib. Dalam bahasa 
Tabel 1. Persentase Kesalahan menurut Tipe Klausa Relatif

\begin{tabular}{|c|c|c|c|c|c|c|}
\hline No. & Tipe Kesalahan & $\begin{array}{c}\text { Juml. } \\
\text { S }\end{array}$ & $\%$ & $\begin{array}{c}\text { Juml. } \\
\text { B }\end{array}$ & $\%$ & $\begin{array}{l}\text { Juml. } \\
\text { Data }\end{array}$ \\
\hline 1 & $\begin{array}{l}\text { Tidak digunakannya pronomina } \\
\text { relatif yang }\end{array}$ & 7 & 100 & 0 & 0 & 7 \\
\hline $2^{*}$ & $\begin{array}{l}\text { Kesalahan penempatan } \\
\text { demonstrativa itu/ini }\end{array}$ & 2 & 100 & 0 & 0 & 2 \\
\hline 3 & $\begin{array}{l}\text { Kesalahan pada klausa relatif yang } \\
\text { merelatifkan subjek }\end{array}$ & 8 & 14.28 & 48 & 85.72 & 56 \\
\hline 4.a & $\begin{array}{l}\text { Kesalahan pada klausa relatif yang } \\
\text { merelatifkan objek: } \\
\text { Kesalahan penggunaan afiks pada } \\
\text { verba pasif } d i-\end{array}$ & 7 & 20.58 & 27 & 79.42 & 34 \\
\hline $4 . b$ & $\begin{array}{l}\text { Kesalahan penempatan persona } \\
\text { pada verba pasif persona }\end{array}$ & 2 & 18.18 & 9 & 81.82 & 11 \\
\hline 4.c & $\begin{array}{l}\text { Kesalahan penggunaan bentuk } \\
\text { verba pasif persona }\end{array}$ & 7 & 77.77 & 2 & 22.23 & 9 \\
\hline 4.d & $\begin{array}{l}\text { Kesalahan penempatan adverbia } \\
\text { pada verba pasif persona }\end{array}$ & 1 & 12.50 & 7 & 87.50 & 8 \\
\hline \multirow[t]{2}{*}{$5^{*}$} & $\begin{array}{l}\text { Kesalahan pada klausa relatif yang } \\
\text { menghilangkan unsur nomina }\end{array}$ & 0 & 0 & 7 & 100 & 7 \\
\hline & & & & & & 124 \\
\hline
\end{tabular}

Inggris pronomina relatif that pada kalimat (25) berikut dapat dilesapkan dan hasilnya merupakan tururan yang gramatikal sebagaimana tampak pada (25a) (dikutip dari DeCapua, 2008: 327). Begitu juga kalimat (26) dan (26b) (dikutip dari Leech et. al, 1982: 98).

(25) Susan bought the book that the teacher liked.

(25a) Susan bought the book $\varnothing$ the teacher liked.

(26) Do you have a typewriter that you can lend me?

(26a) Do you have a typewriter $\varnothing$ you can lend me?)

Hal ini sesuai dengan premis dalam bahasa-antara, sebagaimana telah dikemukakan pada bagian depan tulisan ini, bahwa tata bahasa pemelajar terbuka terhadap pengaruh dari dalam (interferensi B1).
Pada lain pihak, hierarkhi ke-4 dan ke-5, yang ditempati masing-masing oleh penggunaan afiks pada verba pasif $d i$ - dan prefiks pada verba pasif persona, menunjukkan bahwa kaidah pemasifan dalam klausa relatif belum dikuasai dengan baik. Bila dihubungkan dengan tahapan pemerolehan bahasa-antara sebagaimana dikemukakan Brown (1994: 211-213), pemerolehan bentuk pasif pada klausa relatif berada pada tahap kebangkitan (tahap kedua), yaitu mulai terjadi internalisasi kaidah, tetapi pemelajar belum mampu membetulkan kesalahan yang dilakukannya dan masih dijumpai agak banyak kesalahan. Sementara itu, pemerolehan klausa relatif yang merelatifkan subjek dapat dikatakan berada pada tahap stabilisasi (tahap keempat), yakni pemelajar relatif menguasai sistem atau kaidah klausa relatif yang merelatifkan subjek dan dapat memproduksinya tanpa 
banyak kesalahan karena telah dikuasainya kaidah. Sebaliknya, penguasaan terhadap penggunaan pronomina relatif yang dapat dikatakan berada pada tahap kesilapan acak (tahap pertama) karena masih terjadi banyak kesalahan akibat belum terinternalisasikannya kaidah. Adapun pemerolehan bentuk pasif persona pada klausa relatif, khususnya penempatan pronomina persona dan adverbia, dapat dikatakan berada pada tahap sistematik (tahap ketiga), yaitu pemelajar mampu menggunakan pronomina persona dan adverbia pada klausa relatif secara agak konsisten meski kaidah belum sepenuhnya dikuasai.

\section{Strategi Belajar Bahasa dan Pemerolehan Klausa Relatif}

Setiap pemelajar memiliki kapasitas mental dan kognisi yang berbeda. Karena itu, tingkat pemerolehan bahasa asing juga berbeda. Ada banyak faktor yang mempengaruhinya, tetapi dalam penelitian ini hanya faktor strategi belajar bahasa yang akan diperhitungkan untuk menjelaskan hubungan antara faktor individual dan pemerolehan klausa relatif. Strategi belajar bahasa adalah cara yang digunakan oleh pemelajar untuk membantu pemerolehan bahasa target. Strategi belajar bahasa merupakan tindakan spesifik yang diambil oleh pemelajar yang melibatkan bukan hanya aspek kognitif (Oxford, 1990: 8-9).

Berkaitan dengan strategi belajar bahasa tersebut, pertanyaan yang hendak dijawab dalam penelitian ini adalah apakah strategi belajar bahasa yang digunakan berkorelasi dengan pencapaian pemerolehan klausa relatif. Untuk memenuhi maksud tersebut, dilakukan penjaringan data melalui kuesioner mengenai strategi belajar bahasa. Kuesioner yang diadaptasi dari Oxford (1990: 283-291) itu berisi 50 pernyataan yang harus dijawab oleh responden dengan cara memilih apakah pernyataan (tentang cara belajar bahasa) tersebut: (1) tidak pernah atau hampir tidak pernah, (2) umumnya tidak pernah, (3) kadang-kadang, (4) biasanya, atau (5) selalu atau hampir selalu. Daftar pernyataan tersebut dikelompokkan menjadi 6 bagian, yang masing-masing bagian merupakan jenis strategi belajar bahasa. Keenam strategi tersebut adalah (a) strategi memori atau mengingat, (b) strategi kognitif, (c) strategi kompensasi, (d) strategi metakognitif, (e) strategi afektif, dan (f) strategi sosial. Oxford (1990) menyebut strategi (a) s.d. (c) merupakan strategi langsung, yaitu strategi belajar bahasa yang langsung melibatkan bahasa target, sedang strategi (d) s.d. (f) merupakan strategi tak langsung, yaitu strategi belajar bahasa yang mendukung dan mengelola belajar bahasa tanpa melibatkan bahasa target secara langsung. Setelah data terkumpul, dilakukanlah penghitungan skor untuk masing-masing strategi.

Dari kuesioner yang terjaring, dapat dikemukakan hasilnya sebagai berikut. Pertama, $80 \%$ pemelajar hampir selalu menggunakan strategi sosial, artinya sebagian besar skor untuk strategi ini tinggi, yaitu di atas 4.5. Hanya seorang mahasiswa (bernama $\mathrm{Ch}$ ) yang 'biasanya' menggunakan strategi sosial karena skor untuk strategi ini antara 3.5-4.4. Strategi sosial merupakan strategi belajar bahasa dengan cara pemelajar belajar melalui interaksi dengan orang lain. Fakta ini menunjukkan bahwa mayoritas pemelajar hampir selalu membangun kontak atau interaksi dengan orang lain, khususnya dengan orang Indonesia (penutur asli), sehingga memungkinkan lebih banyak praktik berbahasa Indonesia. Karena semua pemelajar tinggal bersama keluarga Indonesia, agaknya mereka memanfaatkan situasi ini untuk meningkatkan pemerolehan BIPA-nya. Dengan kata lain, dalam meningkatkan pemerolehan bahasanya mayoritas pemelajar menggunakan strategi belajar yang tidak langsung melibatkan bahasa target (BIPA). 
Kedua, strategi belajar lain yang mayoritas $(80 \%)$ "biasa" digunakan pemelajar adalah strategi kompensasi. Di antara lima pemelajar, hanya ada satu pemelajar yang "kadang-kadang" saja menerapkan strategi kompensasi ini. Strategi kompensasi adalah strategi yang membantu pe-melajar untuk mengatasi keterbatasan dalam keterampilan berbahasa, baik reseptif maupun produktif. Strategi yang tergolong strategi langsung ini meliputi strategi menebak dan mengatasi keterbatasan dalam berbicara dan menulis. Dalam strategi menebak, pemelajar belajar dengan cara melihat penanda linguistis atau penanda lainnya. Untuk mengatasi keterbatasan dalam berbicara dan menulis, pemelajar antara lain menggunakan cara beralih ke bahasa ibu (B1), meminta bantuan, menggunakan mimik atau gerakan. (Oxford, 1990: 91). Di luar kedua strategi utama tersebut, yaitu strategi sosial dan kompensasi, penerapan strategi belajar lebih bersifat individual karena bervariasi antara satu pemelajar dengan pemelajar lainnya.

Ketiga, rerata umum dari strategi belajar (yang menggambarkan rerata 6 strategi belajar) untuk setiap pemelajar adalah sebagai berikut. Tiga pemelajar $(60 \%)$ memiliki skor rerata antara 3.4-4.4, sedang 2 pemelajar (40\%) memiliki skor rerata $2.5-3.4$. Rinciannya dapat dilihat pada tabel di bawah ini.

Tabel 2. Rerata Umum Strategi Belajar Bahasa

\begin{tabular}{clc}
\hline No. & Nama Pemelajar & Rerata Umum \\
\hline 1 & Cm & 3,8 \\
2 & L & 3,7 \\
3 & S & 3,51 \\
4 & Ch & 3,02 \\
5 & J & 3,20 \\
\hline
\end{tabular}

Keterangan Skor:

Tinggi Selalu atau hampir selalu $\quad 4.5-5.0$ Biasanya 3.5-4.4

Sedang Kadang-kadang 2.5-3.4

Rendah Umumnya tidak pernah $1.5-2.4$ Tidak pernah atau hampir $\quad 1.0-1.4$ tidak pernah
Berdasarkan skor rerata tersebut, dapat disimpulkan bahwa $60 \%$ pemelajar "biasa" menggunakan strategi belajar bahasa untuk meningkatkan kemampuan berbahasanya. Ini berarti bahwa dua pertiga pemelajar secara sadar biasa menggunakan strategi belajar bahasa dalam menguasai BIPA. Sementara itu, sisanya kadang-kadang menggunakan strategi belajar bahasa. Ini mencerminkan bahwa dua pemelajar itu cenderung tidak konsisten menggunakan strategi belajar bahasa.

Dikaitkan dengan pemerolehan klausa relatif, Ch dan J masih menampakkan produksi bahasa Indonesianya yang keinggris-inggrisan; artinya belum banyak terjadi perubahan pada tuturannya. Keduanya belum banyak memproduksi klausa relatif. Meskipun terdapat perkembangan pemerolehan BIPA-nya, tetapi tidak sebaik atau secepat teman lainnya. Hal ini diperkuat dengan hasil analisis kuesioner yang menunjukkan bahwa keduanya memilikik skor rerata umum masing-masing 3,02 dan 3,20 dalam strategi belajar bahasa. Ini berarti bahwa keduanya "kadang-kadang" saja menggunakan strategi belajar bahasa. Hal ini berarti pula bahwa penggunaan strategi belajar bahasa kurang disadari, artinya kadang dia menggunakan strategi bahasa secara sadar, tetapi kadang tidak.

Yang menarik untuk dikemukakan adalah seorang pemelajar $(\mathrm{Cm})$ yang perkembangan pemerolehannya luar biasa. Dikatakan luar biasa karena bisa "melampaui" ketiga teman lainnya yang berada dalam satu tingkat (madya). Pemerolehan klausa relatif pemelajar ini dapat dikatakan cepat dan si pemelajar ini cepat pula memahami pola kaidah tata bahasa. Kemampuan memahami polapola kaidah tata bahasa ini berhubungan erat dengan strategi belajar bahasanya. Berdasarkan isian kuesioner, diketahui bahwa pemelajar ini selalu berusaha menemukan pola-pola dan berusaha untuk 
menjadi pemelajar BIPA yang baik, berusaha untuk memperhatikan bila seseorang sedang berbicara dalam bahasa Indonesia (strategi metakognitif). Selain itu, dia juga selalu meminta orang Indonesia untuk mengoreksi bila dia berbicara, praktik berbicara dalam bahasa Indonesia dengan teman lain, selalu meminta bantuan dari penutur bahasa Indonesia, dan berusaha untuk memulai berbicara dengan bahasa Indonesia (strategi sosial). Dilihat dari rerata umum penggunaan strategi belajar bahasa, pemelajar ini memiliki rerata tertinggi, yaitu 3,8. Hal ini berarti bahwa pemelajar ini menggunakan cara-cara untuk meningkatkan keterampilan berbahasanya secara sadar. Skor tertinggi untuk strategi metakognitif $(4,67)$ dan sosial $(4,50)$ yang dicapai oleh pemelajar ini memperlihatkan bahwa pemelajar ini mengelola belajarnya dengan baik, terencana, dan berusaha membangun interaksi dengan orang lain untuk meningkatkan keterampilan berbahasanya. Usahanya tersebut ternyata membuahkan hasil, yakni pemerolehan tata bahasanya lebih cepat daripada teman lainnya. Hal itu terbukti dari data tulisan yang diamati, tidak banyak kesalahan yang dilakukan pemelajar ini dalam memproduksi klausa relatif.

Berdasarkan uraian di atas, terdapat dua hal yang dapat dicatat. Pertama, penggunaan strategi belajar bahasa berkorelasi positif terhadap pemerolehan klausa relatif. Fakta ini mendukung pendapat Lenneberg (1967), seperti telah dikemukakan pada bagian sebelumnya, bahwa pemelajar dewasa siap mengembangkan strategi belajar dan mampu menggunakannya untuk membantunya dalam mempelajari bahasa. Pada kasus pemelajar bernama $\mathrm{Cm}$ kelihatan jelas bahwa penggunaan strategi belajar secara sadar memungkinkan pencapaian pemerolehan tata bahasanya, termasuk klausa relatif, lebih cepat. Usaha untuk menemukan pola-pola dan mempraktikannya dalam interaksi dengan orang-orang di sekitarnya memungkinkan kaidah tata bahasa (klausa relatif) lebih cepat terinternalisasi. Dengan terinternalisasikannya kaidah, maka kesalahan akan berkurang. Dengan berkurangnya kesalahan itu, maka akan memunculkan bentuk tuturan pemelajar asing yang relatif mendekati ke bentuk tuturan penutur bahasa Indonesia. Di sini terjadi perubahan atau pergeseran identitas terhadap tuturan pemelajar BIPA, yakni dari tuturan yang semula terpengaruh oleh struktur bahasa pertamanya (B1) menjadi tuturan yang mendekati ke bentuk tuturan bahasa target. Seiring dengan perubahan identitas tuturan itu, terjadi pula peningkatan kepercayaan diri dan motivasi pemelajar untuk berbahasa Indonesia. Munculnya peningkatan kepercayaan diri itu akan semakin mendorong pemelajar untuk aktif memproduksi tuturan bahasa Indonesia, termasuk di dalamnya klausa relatif. Kedua, pemerolehan klausa relatif dapat 'menghilangkan' identitas ke-asing-an dari tuturan yang dihasilkan oleh pemelajar BIPA. Semakin tinggi pencapaian pemerolehan dan semakin banyak tipe klausa relatif yang dikuasai, semakin 'tenggelam' ciri-ciri ke-asing-annya dan semakin kuat atau kokoh identitas tuturan pemelajar BIPA ke arah tuturan penutur asli. Dalam konteks bahasa-antara, bila pemerolehan bahasa pemelajar BIPA mencapai tahap stabilisasi atau otonom, hal itu akan mendorong terciptanya identitas baru dari tuturannya.

\section{SIMPULAN}

Dari paparan di atas dapat dikemukakan simpulan sebagai berikut. Pertama, urutan pemerolehan klausa relatif menggambarkan sekaligus urutan penguasaan dan tingkat kesulitan setiap tipe. Atas dasar itu, pengembangan materi ajar BIPA dan pengajarannya seyogyanya memperhitungkan tingkat kesulitan tersebut. Kedua, dalam konteks bahasa-antara, pemerolehan klausa relatif berkemung- 
kinan melewati tahapan yang memperlihatkan adanya interferensi B1 terhadap B2. Semakin pemelajar menguasai klausa relatif, semakin tipis interferensi yang terdapat pada klausa yang dihasilkan. Ketiga, penggunaan strategi belajar bahasa berkorelasi positif terhadap pemerolehan klausa relatif. Penggunaan strategi belajar yang dilakukan secara sadar memungkinkan pencapaian pemerolehan klausa relatif lebih cepat. Keempat, pemerolehan bahasa asing (BIPA) menyebabkan pergeseran atau perubahan "identitas" tuturan pemelajar asing dari pengaruh struktur bahasa pertama ke bahasa target. Semakin tinggi pencapaian pemerolehan dan semakin banyak tipe klausa relatif yang dikuasai, semakin 'tenggelam' ciriciri ke-asing-annya dan semakin kuat atau kokoh identitas tuturan pemelajar BIPA ke arah tuturan penutur asli. Dengan kata lain, tercapainya tingkat pemerolehan klausa relatif membawa perubahan identitas tuturan pemelajar BIPA.

\section{UCAPAN TERIMA KASIH}

Artikel ini merupakan bagian dari hasil penelitian yang didanai oleh Fakultas Ilmu Budaya UGM dengan skema Penelitian Payung Kompetisi B Tahun Anggaran 2013. Ucapan terima kasih disampaikan kepada Dekan dan Wakil Dekan Bidang Penelitian dan Kerjasama FIB UGM yang telah menyediakan dana untuk penelitian ini. Terima kasih juga disampaikan kepada Ketua Inculs (Indonesian Language and Culture Learnng Service) dan mahasiswa peserta Kursus Intensif Bahasa dan Budaya Indonesia yang tergabung dalam Program Summer Course USINDO 2013 yang bersedia membantu pelaksanaan penelitian ini.

\section{DAFTAR PUSTAKA}

Abdul-Hamied, Fuad. 2001. "Pembelajaran Bahasa Indonesia bagi Penutur Asing: Isu dan Realita". Prosiding Konferensi Internasional Pengajar BIPA (KIPBIPA) IV, Denpasar.
Alwasilah, A.C. 2006. “Dosen BIPA Buta Politik: Analisis Isi Prosiding KIPBIPA". Prosiding KIPBIPA VI, Serang, Banten, 11-14 Juli.

Biro Perencanaan dan Kerjasama Luar Negeri Kemendiknas. 2007. Pengembangan Program Bahasa Indonesia untuk Penutur Asing. Jakarta: Kemendiknas.

Brown, H.D. 1994. Principles of Language Learning and Teaching. California: Pearson Hall Regents.

Chaudron, Craig. 2003. "Data Collection in SLA Research", dalam Catherine J.D. and Michael H.L. (ed.), The Handbook of Second Language Acquisition. Oxford: Blackwell Publishing Ltd.

DeCapua, A. 2008. Grammar for Teachers: A Guide to American English for Native and Non-Native Speakers. New York: Springer.

Ellis, R. 2003. Second Language Acquisition. New York: Oxford University Press.

Gass, S.M. \& L. Selinker. 2001. Second Language Acquisition: An Introductory Course. Mahwah, NJ: Erlbaum.

Greenbaum, S. 1996. The Oxford English Grammar. Oxford: Oxford University Press.

Kakazu, K. 2011. “Implementation of Proficiency Standards into JapaneseLanguage Education: Approach by The Japan Foundation". Makalah disajikan pada The Second Annual International Symposium of Foreign Language Learning (AISOFOLL). SEAMEO QITEP in Language, Jakarta, 29-30 November 2011.

Kartika, D. 2006. "Performansi Antarbahasa (Interlanguage) Tindak Tutur Memohon Pembelajar BIPA dari Jepang: Kajian Tindak Tutur Tidak Langsung". Makalah KIPBIPA VI di Universitas Sultan Ageng Tirtayasa, Banten, 11-14 Juli 2006.

Krashen, S.D. 1982. Principles and Practice in Second Language Acquisition. First internet edition (2009). Tanpa Kota Terbit: Pergamon Press Inc. 
Kridalaksana, H. 1986. Kelas Kata dalam Bahasa Indonesia. Jakarta: PT Gramedia.

Kridalaksana, H. 2008. Kamus Linguistik. Jakarta: PT Gramedia Pustaka Utama.

Language Policy Division, Council of Europe. 2001. Common European Framework of Reference for Languages. Cambridge: Cambridge University Press.

Language Policy Division, Council of Europe. Tanpa Tahun. A Teacher's Guide to the Common European Framework. Tanpa Kota Terbit: Pearson.

Leech, G., Margaret D., and Robert H. 1982. English Grammar for Today, London: The Macmillan Press.

Muliastuti, L. 2006. "Kesalahan ContohContoh Bahasa Indonesia dalam Kamus Bahasa Indonesia-Korea dan Implikasinya pada Pengajaran BIPA". Makalah KIPBIPA VI di Universitas Sultan Ageng Tirtayasa, Banten, 11-14 Juli 2006.

Norris, J. and Lourdes Ortega. 2003. “Defining and Measuring SLA", dalam Catherine J. Doughty and Michael $\mathrm{H}$. Long (eds.), The Handbook of Second Language Acquisition. First Edition. Malden: Blackwell Publishing Ltd.

Nurmayanti. 2012. "Pemerolehan Bahasa Kedua Anak (Studi Kasus di Briton International School)". Tesis. Yogyakarta: UGM.
Oxford, R.L. 1990. Language Learning Strategies: What Every Teacher Should Know. Boston: Heinle \& Heinle.

Saville-Troike, M. 2006. Introducing Second Language Acquisition. Cambridge: Cambridge University Press.

Schleppegrell, M. 1987. "The Older Language Learner", dalam ERIC Clearinghouse on Languages and Linguistics; http://www.cal.org/resources/archive/ digest/ 1987olderlearner.html.

Sudaryanto. 1993. Metode dan Aneka Teknik Analisis Bahasa: Pengantar Penelitian Wahana Kebudayaan secara Linguistis. Yogyakarta: Duta Wacana University Press.

VanPatten, B. and Alessandro G.B. 2010. Key Terms in Second Language Acquisition. London: Continuum International Publishing Group.

Wiedarti, P. 2010. “Menuju Pengembangan Program Bahasa Indonesia untuk Penutur Asing dengan Mengacu pada Common European Framework of References for Languages dan Genre". Makalah disajikan pada The First Annual International Symposium of Foreign Language Learning (AISOFOLL): Exploring Standards for Foreign Language Learning in Southeast Asia, SEAMEO QITEP in Language, Jakarta, 20 Oktober 2010. 


\section{Lampiran 1. Contoh Hasil Pengolahan Kuesioner Strategi Belajar Bahasa bagi Pemelajar} BIPA

Nama: $\mathrm{Cm}$

\begin{tabular}{|c|c|c|c|c|c|c|c|c|c|c|c|c|}
\hline & \multicolumn{2}{|c|}{ Bag. A } & \multicolumn{2}{|c|}{ Bag. B } & \multicolumn{2}{|c|}{ Bag. C } & \multicolumn{2}{|c|}{ Bag. D } & \multicolumn{2}{|c|}{ Bag. E } & \multicolumn{2}{|c|}{ Bag. F } \\
\hline & No. & Jwb. & No. & Jwb. & No. & Jwb. & No. & Jwb. & No. & Jwb. & No. & Jwb. \\
\hline & 1. & 4 & 10. & 3 & 24. & 5 & 30. & 5 & 39. & 4 & 45. & 4 \\
\hline & 2. & 4 & 11. & 5 & 25. & 2 & 31. & 4 & 40. & 4 & 46. & 5 \\
\hline & 3. & 2 & 12. & 5 & 26. & 3 & 32. & 5 & 41. & 1 & 47. & 5 \\
\hline & 4. & 2 & 13. & 5 & 27. & 5 & 33. & 5 & 42. & 2 & 48. & 5 \\
\hline & 5. & 2 & 14. & 5 & 28. & 4 & 34. & 4 & 43. & 1 & 49. & 4 \\
\hline & 6. & 4 & 15. & 4 & 29. & 5 & 35. & 5 & 44. & 1 & 50 & 4 \\
\hline & 7. & 1 & 16. & 5 & & & 36. & 4 & & & & \\
\hline & 8. & 4 & 17. & 2 & & & 37. & 5 & & & & \\
\hline & 9. & 3 & 18. & 5 & & & 38. & 5 & & & & \\
\hline & & & 19. & 4 & & & & & & & & \\
\hline & & & 20. & 5 & & & & & & & & \\
\hline & & & 21. & 5 & & & & & & & & \\
\hline & & & 22. & 5 & & & & & & & & \\
\hline & & & 23. & 4 & & & & & & & & \\
\hline JUMLAH & \multicolumn{2}{|c|}{26} & \multicolumn{2}{|c|}{62} & \multicolumn{2}{|c|}{24} & \multicolumn{2}{|c|}{42} & \multicolumn{2}{|c|}{13} & \multicolumn{2}{|c|}{27} \\
\hline $\begin{array}{c}\text { Rata-Rata } \\
\text { Bagian }\end{array}$ & \multicolumn{2}{|c|}{$\begin{array}{c}26 / 9 \\
=2,89\end{array}$} & \multicolumn{2}{|c|}{$\begin{array}{r}62 / 14 \\
=4,43\end{array}$} & \multicolumn{2}{|c|}{$\begin{aligned} & 24 / 6 \\
= & 4,00\end{aligned}$} & \multicolumn{2}{|c|}{$\begin{array}{c}42 / 9 \\
=4,67\end{array}$} & \multicolumn{2}{|c|}{$\begin{array}{c}13 / 6 \\
=2,16\end{array}$} & \multicolumn{2}{|c|}{$\begin{array}{c}27 / 6 \\
=4,50\end{array}$} \\
\hline $\begin{array}{l}\text { Rata-Rata } \\
\text { Keseluruhan }\end{array}$ & \multicolumn{12}{|c|}{$\begin{array}{c}194 / 50 \\
=3,88\end{array}$} \\
\hline
\end{tabular}

\section{Keterangan:}

Bagian A : Strategi memori/mengingat

Bagian B : Strategi kognitif

Bagian D : Strategi metakognitif

Bagian C : Strategi kompensasi

Bagian E : Strategi afektif

Bagian F : Strategi sosial

Rata-rata keseluruhan adalah jumlah skor tiap bagian dibagi banyaknya pertanyaan yang terjawab/terisi.

\section{Lampiran 2. Grafik Profil Strategi Belajar Bahasa}

$\underline{\underline{C m}}$

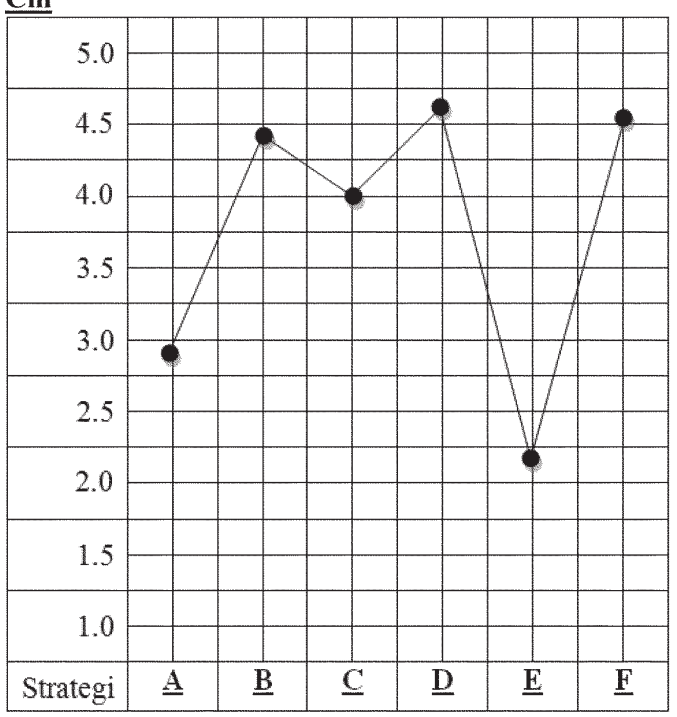

Keterangan:

Tinggi $\quad 4.5-5.0$ Selalu atau hampir selalu $3.5-4.4$ Biasanya

Sedang 2.5-3.4 Kadang-kadang

Rendah 1.5 - 2.4 Umumnya tidak pernah 1.0 - 1.4 Tidak pernah atau hampir pernah 